\title{
INSIGHTS IN TO THE EMPLOYEE TRAINING PROGRAMMES OF INDIAN CEMENT INDUSTRY: AN EMPIRICAL STUDY
}

\author{
${ }^{1}$ Ms. Jeevana Chitreddy, ${ }^{2}$ Prof.G.L. Narayanappa \\ ${ }^{1}$ Research Scholar,Dept. of Management,Dravidian University, Kuppam \\ ${ }^{2}$ Dean, School of Commerce and Management,Dravidian University, Kuppam
}

Article DOI: https://doi.org/10.36713/epra7433

DOI No: 10.36713/epra7433

\section{STATEMENT OF THE PROBLEM}

The 'ABC' Cement Industries Ltd has entrenched in the year 1955 in the most economically disadvantaged and industrially deprived location of Southern India. After words, the industry nourished as a very big cement industry in the region. Subsequently, the founders put their sustained efforts to emerge the ABC industry as a market leader. From the past half decade the company was creating thousands of employment opportunities to the unemployed youth in the region. At the outset the $\mathrm{ABC}$ cement industry produced only $200 \mathrm{mts}$ per day and later it has increased its production to 4000 TPDs after contraption. The then dynamic founder entrepreneur under whose custodianship the ABC cement industry was flourished, such founder was passed away and the industry is looked after by their heriditaries.

\section{IMPORTANCE OF EMPLOYEE TRAINING}

The era of economic liberalisation and privatisation around the globe have been drastically streamlined the industrial sector in general and the cement industries in particular. The cement industry enormously encourages the growth of Indian economy during the cut-throat competition of industries.

The object of this study includes the importance of employee training factors which influence the role of training of employees to assess the nourishment of future economy of cement industry. It is realised that there is a need of convergence of employee training in cement industries for overall upward advancement of cement industries in today's corporate world. Since, the advent of liberalisation with an object of moulding the cement industries sector more human resource oriented and expansion of the role of cement industries in the growing economy and the role of privatisation and the direct foreign investment have given the boost to the modern cement industry. The ABC Cement Industries Ltd. has realised the relative importance of employee training for deputing their vital employees for world class institutions for training of employees.

With the changing technology taken place in administration of cement industries, the designing of new employee training programmes keeping in view of the organisational skill requirements and employees calibre has become tough. In view of this catastrophic situation, the $\mathrm{ABC}$ cement industry should compile the new human resource plans and design the new employee training programmes with thousand eyes.

Further, it is realised that the analysis of specifications various methods of employee training programmes that are required for training the employees of this cement industry are vital parameters for successful running of the organisations. In addition, it is also noticed from the incidents of past era that the outdated employee training programmes are imbibing laggard technological skills into the minds of employees/workers of $\mathrm{ABC}$ cement industry. In spite of several attempts made by the $\mathrm{ABC}$ cement industry with regard to the employee training methods, several disruptions were taking place in attaining the proper implementation of this facets. Further, it is noticed that various skills imbibed into the minds of the employee/workers in the training 
programme will immediately influence the total productivity of the ABC cement industry. Hence, the principle aim of training is overall augmentation of the productivity of the organisation.

In the era of globalisation, the success of cement industry very much depends upon the adoption of rational employee training programmes to their employees/workers by the ABC cement industry. The adoption of scientific methods for imparting of latest training methodologies for their employees is inevitable for $\mathrm{ABC}$ cement industry towards the maximisation of profits.

\section{SELECT REVIEW OF LITERATURE}

Doris B. Collins $(2002)^{1}$ has stated that the best program for the organisation is the one where the indispensable structure of the organisation drives the content of the training program. Major issues emerge when the objectives and goals of the training program are not connected to the overall strategy of the organisation. To be suitable, the training program should initially be went through before by a prerequisite assessment to guarantee that the program targets meet the specific necessities of the organisation and are associates with the organisational strategy. The best programs incorporate adult learning abilities. Programs should represent the individual learning styles of a different gathering of pioneers and chiefs.

Desseler $(2008)^{2}$ observes the training further and stated that as the methods for giving new or current work force the skills they need to perform at their different jobs. Continuing, he considers training as the hallmark of good administration and in this way when managers ignore training, they are doing as such to the great disadvantages of the organizations they are managing. This is on the grounds that high potential workers do not still guarantee that they will perform on the job. This is the reason every employee should understand what the board wants him to do a how he must do it. Training therefore, has had a genuinely amazing record of affecting organizational effectiveness.

Monappa and Saiyadain $(2008)^{3}$ have defined training as "the teaching or learning activities carried on for the basic purpose of aiding individuals of an organization to gain and supply the knowledge, skills, abilities and attitude required by that organization. It is the act of increasing the knowledge and skill of an employee for doing a particular job." Training in this way needs to be seen by managements of every organization as a long-term investment in its human resource.

Armstrong $(2009)^{4}$ has separated the training from development by articulating his idea that advancement is intended to procure new knowledge and abilities that help to advance into some future occupation prerequisites while training helps in acquiring those capabilities that empower the workers to perform better in their current jobs.

Markos and Sridevi(2010) ${ }^{5}$ have proposed the training and development as a significant factor of workers. It will prompt greater engagement on their part if they perceive more growth. Workers in these days are not satisfied with the old style of authoritarian management, as they require job satisfaction, operational autonomy and status.

Jehanzeb $(2012)^{6}$ has opined that the research shows the advantages of training and development for the employee and organisation. The old employees are more capable instead of the new workers for the organisation. But if any new technology or assignment is given to the employee than there is a need of training emerge. The more the workers gain proficiency with the more they become compelling for the organisation. At the end if his research it is clarifies that the employee is the resource or an asset for the organisation so that is the reason the training and development program is exceptionally fundamental for the workers.

\section{SCOPE OF THE STUDY}

The scope this study is confined to the H.R. Planning practices of ' $\mathrm{ABC}$ ' Cement industries and it can not be made any generalisation to other similar industries

\section{OBJECTIVES OF THE STUDY}

The basic objectives of the study:

(i) To explore the customary practice of employee training programmes in 'ABC' Cement Industries Ltd.;

(ii) To appraise the level of satisfaction/dissatisfaction of employees/workers towards the customary practice of employee training programmes in 'ABC' Cement Industries Ltd;

(iii) To look out the factors for dissatisfaction of employees/workers towards the customary practice of employee training programmes in 'ABC' Cement Industries Ltd.; and

(iv) To bestow the suitable remedial measures to surmount the discontentment prevailed among the employees/workers towards the customary practice of employee training programmes in 'ABC' Cement Industries Ltd.

\section{RESEARCH METHODOLOGY}

The methodology consists of data collection from primary as well as secondary sources. Through the survey method the first hand information was 
collected from 60 sample respondents from the study unit.

\section{SAMPLE DESIGN AND SIZE}

A Purposive-cum-convenient sampling procedure was followed and 60 respondents were chosen as sample respondents.

\section{ANALYSIS OF THE DATA}

The information collected from the sample respondents was processed and tabulated scientifically and several statistical tools like (i) Independent sample t-test; (ii) Weighted mean scores; (iii) ANOVA; and (iv) Correlation analysis are calculated at appropriate junctures and the inferences were drawn

\section{RESEARCH FINDINGS}

1) Due importance is not given for organisational requirements while imparting training and while deputing the employees/workers to the various employee training programmes. Deputation of employees to the various training programmes is purely depends on the whims and fancies of higher officials. Really deserving and eligible employees/workers are not at all deputing for employee training programmes. (23.33\%).

2) The very design of training is not designed in accordance with the needs of the organisation and hence there is a mismatch between the skills required by the organisation and the actual skills imparted in the training $(21.66 \%)$.

3) The present training procedure is not at all imbibing any new skills to the employees/workers/participants to discharge updated technological professional responsibilities which involve certain technical knowledge. Whenever any technological problems arised in the operation of the plant and machinery the organisation needs to depend on outside technological experts which involves hugeexpenditure (18.33\%).

4) The present employee training programmes are not at all motivating the work attitude, professional conduct and character of the employee/workers. Due to this reason, the professional working performance of the employees/workers was not at all enhanced $(20.00 \%)$.

5) The present programmes of employee training are not at all helping to develop the organisational performance and also not playing any vital role in enhancing the employees' calibre and organisational productivity $(16.66 \%)$.

\section{SUGGESTIONS}

1. Proper importance and due weightage should be given to the organisational training requirements while deputing the employees to the various training programmes. Further, the skilled employees/workers who can grasp the training contents and inputs in short span should only be deputed for training. So, that they can learn, grasp and implement the skills learned in the training programme for organisational effectiveness. While deputing the employees for training, the too much involvement of higher officials should be minimised. So that the really deserving and result oriented employees can be deputed for training to achieve organisational effectiveness.

2. The basic design and scientific structure of training depending upon the requirements of the organisation should be fabricated by the senior officials of the organisation. So that the mismatch between the skills really required by the organisation and the actual skills imparted in the training can be ameliorated.

3. It is proposed to incorporate the latest contents into these training programmes such as professional technological responsibilities which involves certain portion of technical knowledge to discharge updated technological job responsibilities and the same should be imbibed into theses training progress. So that the concerned employees can update their skills in the relevant area and the dependence on outside experts for operation of plant and machinery, which involves huge expenditure can be minimised.

4. Further, the proposed employee training programmes should be capable of psychologically motivating the employees work attitude, behaviour, professional ethics, organisational culture, professional conduct and character of employees in order to increase the professional working performance of the employees/workers for maximising the organisational productivity.

5. The prime motto and outcome of the proposed training programmes for the employees should be primarily capable of building and developing the organisational performance in principle. Further, the proposed and enhanced calibre of the employees/workers should be capable of enormously enhancing the organisational productivity for maximisation 
of further profits and building of reputation in the corporate sector.

\section{REFERENCES}

1. Doris B. Collins Elwood F. Holton III, The effectiveness of managerial leadership development programs: A meta-analysis of studies from 1982 to 2001, Human Resource Development Quarterly, Volume15, Issue2 Summer 2004, Pp 217-248.

2. Dessler, G. (2008). Human Resource Management 11 th ed. Pearson International Edition.

3. Monappa, A \& Saiyadain, M. (2008). Personnel Management 2nd ed. Tata McGraw-Hill, New Delhi.

4. Armstrong, M. (2009). Armstrong's handbook of human resource management practice (11th ed.). London (UK) and Philadelphia (USA): Kogan Page Limited.

5. Sridevi, M.S., Markos, S., (2010). Employee Engagement: The Key to Improving Performance. International Journal of Business and Management, 5(12), 89-96.

6. Khawaja Jehanzeb, D. N. (2012). Training and Development Program and Its Benefits to Employees and Organizations. Far East Journal of Psychology and Business, 59-71. 